\title{
EHMTI-0389. Occipital nerve stimulation in the treatment of chronic migraine: experiences of two years
}

\author{
A Göbel ${ }^{1 *}$, C Göbel ${ }^{2}$, A Heinze ${ }^{3}$, K Heinze-Kuhn $^{3}$, I Petersen ${ }^{3}$, C Meinecke ${ }^{3}$, S Clasen $^{3}$, D Rasche ${ }^{4}$, HM Mehdorn 5 , \\ H Göbel ${ }^{3}$
}

From 4th European Headache and Migraine Trust International Congress: EHMTIC 2014

Copenhagen, Denmark. 18-21 September 2014

\section{Background}

Occipital nerve stimulation (ONS) as a special form of neuromodulation has proven to be an important method in the treatment of therapy refractory chronic migraine.

\section{Objective}

Severely affected patients, not responding to other treatment options, present in our specialised headache centre and treatment network to put up the medical indication for ONS. The patient characteristics and satisfaction rates are analysed over the time span of two years.

\section{Methods}

Descriptive analysis of patient characteristics, therapy satisfaction rates and disability due to migraine of patients treated with ONS since November 2011.

\section{Results}

ONS was used in a total of 43 patients due to therapyresistant migraine (age $44.98 \pm 10.6$ years, range 22-69 years, 36 women, 7 men). Migraine had before existed an average of $28.47 \pm 11.5$ years. When starting treatment, the average MIDAS score was $129.14 \pm 58.73$, after one year it dropped to $87.44 \pm 45.69(\mathrm{p}<0.001)$. In the followup studies during the time of analysis, patients were asked whether they would choose to be treated with ONS again (answers: yes/ambivalent/no). In the follow up studies 1-6, the following answers were found: (1) 56.1/41.5/2.4; (2) $56.8 / 32.4 / 10.8$; (3) $51.9 / 44.4 / 3.7$; (4) $55.6 / 44.4 / 0$; (5) $58.3 /$ $41.7 / 0$; (6) 60.0/20.0/0.

'Department of Neurology, University Hospital Schleswig Holstein Campus Lübeck, Lübeck, Germany

Full list of author information is available at the end of the article

\section{Conclusion}

ONS led to a positive evaluation in more than half of patients treated, despite therapy-resistance beforehand. The burden of chronic migraine can be significantly lifted through ONS. Only a very small fraction of patients would not choose this therapy again.

\section{Authors' details}

'Department of Neurology, University Hospital Schleswig Holstein Campus Lübeck, Lübeck, Germany. ${ }^{2}$ Department of Neurology, University Hospital Cologne Germany, Köln, Germany. ${ }^{3}$ Kiel Migraine and Headache Centre, Kiel Pain Centre, Kiel, Germany. ${ }^{4}$ Department of Neurosurgery, University Hospital Schleswig Holstein Campus Lübeck, Lübeck, Germany. ${ }^{5}$ Department of Neurosurgery, University Hospitals Schleswig-Holstein Campus Kiel, Kiel, Germany.

Published: 18 September 2014

doi:10.1186/1129-2377-15-S1-M5

Cite this article as: Göbel et al.: EHMTI-0389. Occipital nerve stimulation in the treatment of chronic migraine: experiences of two years. The Journal of Headache and Pain 2014 15(Suppl 1):M5.

Submit your manuscript to a SpringerOpen ${ }^{\circ}$ journal and benefit from:

$\checkmark$ Convenient online submission

- Rigorous peer review

- Immediate publication on acceptance

- Open access: articles freely available online

- High visibility within the field

- Retaining the copyright to your article

Submit your next manuscript at $\gg$ springeropen.com

\section{SpringerOpen ${ }^{\circ}$}

(C) 2014 Göbel et al; licensee Springer. This is an Open Access article distributed under the terms of the Creative Commons Attribution License (http://creativecommons.org/licenses/by/2.0), which permits unrestricted use, distribution, and reproduction in any medium, provided the original work is properly cited. 